\title{
THROMBOCYTE INDICES RELATION WITH GESTATIONAL HYPERTENSIVE DISORDERS.
}

\author{
Mustafa Ayhan Ekici ${ }^{1}$ iD, Mehmet Kayhan² (D)
}

\author{
1- Abant Izzet Baysal University, Department of Gynecology and Obstetrics \\ 2- Abant Izzet Baysal University, Department of Family Medicine
}

\begin{abstract}
The aim of this study to evaluate relationship between thrombocyte indices, Red cell distribution width (RDW) and gestational hypertensive disorders. This study is a retrospective cross sectional study performed between 2009 - 2019. Total 583 pregnant women were included in this study; 123 severe preeclampsia (PE), 175 mild-PE, 73 gestational hypertension (GH), 41 chronic hypertension and 171 healthy pregnant women (control group). Statistical Package for Social Science version 23.0 is used for statistical analysis. Kolmogorov-Smirnov, Anova, Kruskal-Wallis and Mann Whitney $U$ tests are used for interpretation of data. Statistical significance is considered if $p<0.05$. Mean age and number of pregancies were indifferent among five groups. Mean Platelet Volume (MPV) was significantly higher in severe-PE group $(p<0.001)$ and insignificantly different among mild-PE, GH, chronic hypertension and control groups $(p=0.116)$. Platelet count $(P C)$ was found significantly lower in severe-PE group $(p=0.01)$ and found indifferent among mild$\mathrm{PE}, \mathrm{GH}$, chronic hypertension and control groups $(p=0.110)$. RDW was found significantly higher in severe-PE group than other groups $(p=0.01)$ and significantly higher in mild-PE group than $\mathrm{GH}$, chronic hypertension and control groups $(p=0.01)$ but insignificantly different among $\mathrm{GH}$, chronic hypertension and control groups $(p=0.501)$. Platelet distribution width (PDW) was found significantly lower in control group than other groups $(p<0.001)$ and found indifferent among mild- $P E, G H$, chronic hypertension and severe-PE groups $(p=0.621)$. Neutrophil lymphocyte ratio (NLR), hemoglobin, Plateletcrit and Platelet lymphocyte ratio (PLR) were found unchanged among the groups. MPV, RDW, PDW, NLR, PC, Plateletcrit and PLR were indifferent among GH and chronic hypertension groups. MPV and RDW were found higher and PC was found lower in severe-PE. RDW levels elevation was found higher in accordance with the severity of preeclampsia.PDW was found higher in gestational hypertensive disorders than healthy pregnant women.
\end{abstract}

Keywords: Preeclampsia, hypertension, thrombocyte indices, MPV, PDW, RDW, NLR.

\begin{abstract}
GESTASYONEL HIPERTANSIF BOZUKLUKLAR ile TROMBOSIT BELIRTEÇLERININ İLiŞKisi
Çalışmanın amacı trombosit indeksleri, eritrosit dağılım genişliği (RDW) ve gestasyonel hipertansif bozukluklar arasındaki ilişkiyi değerlendirmektir. Çalışma 2009-2019 yılları arasında yapılan retrospektif kesitsel bir çalışmadır. Toplam 583 hamile kadın çalışmaya dahil edildi; 123 şiddetli preeklampsi (PE), 175 hafif PE, 73 gestasyonel hipertansiyon (GH), 41 kronik hipertansiyon ve 171 sağlıklı gebe (kontrol grubu). Verilerin yorumlanmasında Kolmogorov-Smirnov, ANOVA, Kruskal-Wallis ve Mann Whitney $U$ testleri kullanılmıştır. İstatistiksel anlamlılık $p<0.05$ olduğunda kabul edildi. Ortalama yaş ve gebelik sayısı açısından beş grup arasında fark bulunmadı. Ortalama Trombosit Hacmi (MPV) şiddetli PE grubunda anlamlı derecede yüksek $(p<0.001)$ bulundu. Hafif PE, GH, kronik hipertansiyon ve kontrol grupları arasında MPV değerleri anlamlı derecede farklı değildi $(p=0.116)$. Trombosit sayısı $(P C)$ şiddetli PE grubunda anlamlı olarak düşük bulundu $(p=0.01)$. Hafif $P E, G H$, kronik hipertansiyon ve kontrol grupları arasında $P C$ değerleri arasında anlamlı farlıık bulunmadı $(p=0.110)$. RDW, şiddetli PE grubunda diğer gruplardan $(p=0.01)$, hafif $P E$ grubunda $\mathrm{GH}$, kronik hipertansiyon ve kontrol gruplarından $(p=0.01)$ anlamlı olarak daha yüksek bulundu. Gestasyonel Hipertansiyon, kronik hipertansiyon ve kontrol grupları arasında RDW değerleri anlamlı derecede farklı bulunmadı. ( $p=0.501)$. Trombosit dağılım genişliği (PDW) kontrol grubunda diğer gruplara göre anlamlı olarak düşük bulundu $(p<0.001)$. Hafif PE, GH, kronik hipertansiyon ve şiddetli PE grupları arasında PDW değerleri arasında farklıık bulunmadı $(p=0.621$ ). Nötrofil lenfosit oranı (NLR), hemoglobin, Trombosit ve Trombosit lenfosit oranı (PLR) gruplar arasında farklılık göstermedi. MPV, RDW, PDW, NLR, PC, Trombosit ve PLR değerleri GH ve kronik hipertansiyon grupları arasında farlılık göstermedi. Şiddetli PE'de MPV ve RDW daha yüksek ve PC daha düşük bulundu. Preeklempsi şiddeti artıkça RDW düzeylerinde artış olmaktadır. Gestasyonel hipertansif hastalıklarda RDW seviyeleri sağlıkı gebelerden daha yüksek bulunmuştur.

Anahtar Kelimeler: Preeklempsi, hipertansiyon, Trombosit indeksleri , MPV, PDW, RDW, NLR.
\end{abstract}

Sorumlu Yazar / Corresponding Author: Asst. Prof. Dr. Mustafa Ayhan Ekici

Abant Izzet Baysal University, Department of Gynecology and Obstetrics. Bolu, Turkey

e-posta / e-mail: mayhanekici@hotmail.com

Geliş Tarihi / Received: 02.12.2019, Kabul Tarihi / Accepted: 05.01.2020

Nasıl Atıf Yaparım / How to Cite: Ekici MA, Kayhan M. Thrombocyte Indices Relation with Gestational Hypertensive Disorders. ESTÜDAM Public Health Journal. 2020;5(1):121-30. 
$\mathrm{H}$ ypertension complicates about 6$10 \%$ of all pregnancies. Hypertensive disorders of pregnancy include chronic hypertension, gestational hypertension, pre-eclampsia and chronic hypertension with superimposed pre-eclampsia (1). Gestational hypertension $(\mathrm{GH})$ is defined as hypertension that develops in pregnancy after 20 weeks gestation and which returns to normal within 12 weeks postpartum. Preeclampsia develops in the third trimester in approximately 15$17 \%$ of women with pregnancy hypertension. Pre-eclampsia complicates approximatelly $3-4 \%$ of pregnancies. Preeclampsia is typically characterised by new-onset hypertension and proteinuria in pregnancy (with proteinuria defined as the urinary excretion of $\geq 300 \mathrm{mg}$ of protein in $24 \mathrm{~h}$ ). It is classified as mild- PE and severe-PE forms (2). Severe-PE may be complicated with eclampsia, HELLP (hemolysis, elevated liver enzymes and low platelet count ) syndrome, pulmonary edema and abruptio placentae and may lead to maternal-fetal morbidity and mortality (3). Chronic hypertension with superimposed pre-eclampsia is diagnosed when a woman with chronic hypertension develops new-onset proteinuria, thrombocytopoaenia or any of the other systemic features of the preeclampsia syndrome. Pre-eclampsia is characterised by poor placental perfusion and a systemic disease process that can involve multiple organ systems. The etiology and pathogenesis of PE is

\section{Material and Method}

This study is conducted as a retrospective cross-sectional study and approved by Abant Izzet Baysal University, local ethics committee (decision no:2019/202). The research is conducted by evaluation of medical records of inpatient and outpatient obstetrical patients in Abant Izzet Baysal considered multifactorial. It's thougt that, multiple organ responses due to vascular endothelial damage and systemic inflammatory reaction is the most important factor in pathogenesis of preeclampsia (4). Activation of thrombocytes in preeclamptic women were shown as elevated plasma levels and augmented thrombocyte surface activity of thrombocyte activating markers $(5,6)$. Some studies suggest that there may be a relationship between preeclampsia and platelet indices (7-9).

Preeclampsia has been an important public health hazard in all over the world because of the increasing maternal and perinatal morbidity and mortality. There are many difficulties in the prevention and management of preeclampsia. Many clinical and biochemical tests have been recommended for early detection of preeclampsia, but they are unpractical for general use. Currently, there is no a reliable and cost-effective screening test for preeclampsia that can be proposed for use in most developing countries. The use of simple hematological markers for the severity of hypertension during pregnancy may be useful in early diagnosis and referral of patients to appropriate centers in first-line pregnant follow-up. Our study is different from other studies because it includes all hypertensive diseases during pregnancy. The aim of this study was to investigate whether there is a relationship between severity of gestational hypertensive disorders and hematological parameters.

University Hospital and Bolu state hospital, between January 2009 and November 2019. Data was identified from a retrospectivelly maintained departmental billing database. The database was maintained with quality assurance by a database specialist and searchable through International 
Classification of Disease codes, Current Procedural Terminology. Demographic characteristics, symptoms, laboratory data and examination notes were collected from medical records.

583 pregnant women were included in this study, 123 of them were severe -PE, 175 were mild- PE, 73 were $\mathrm{GH}, 41$ were cronic hypertension and 171 were healthy pregnant women (control group).

\section{study \\ Criteria in recruitment to the}

The patients are identified as with gestational hypertension (GH), mild-PE and severe-PE due to the American College of Obstetrics and Gynecology (ACOG) Practice Bulletin criterias (10). Hypertension is defined as systolic blood pressure higher than $140 \mathrm{~mm} \mathrm{Hg}$ or diastolic blood pressure higher than 90 $\mathrm{mm} \mathrm{Hg}$ on two occasions that are 4-6 h apart. Chronic hypertension was considered as hypertension that existed before pregnancy or was detected before the 20th week of pregnancy. $\mathrm{GH}$ is defined as hypertension that develops in pregnancy after 20 weeks gestation with no known history of hypertensive disorder.

Pregnant women of $20^{\text {th }}$ weeks or greater with hypertension and have an additionally 24 hour proteinuria value of $\geq$ $0.3 \mathrm{gr}$ are defined as mild-PE. Criteria of severe-PE have been based on the severity of hypertension (e.g. a systolic pressure $\geq 160 \mathrm{mmHg}$, diastolic pressure $\geq 110 \mathrm{mmHg}$ on at least two occasions 6 h apart,6 or both), and pregnancy outcome (e.g. pre-eclampsia complicated by fetal death, preterm birth or eclampsia). Other criteria used to identify severe pre-eclampsia include proteinuria of $5 \mathrm{~g}$ or higher in a 24-h urine specimen or $3+$ or greater on two random urine samples, oliguria of $<500 \mathrm{ml}$ in $24 \mathrm{~h}$, cerebral or visual disturbances, pulmonary oedema or cyanosis, epigastric or right upper-quadrant pain, impaired liver function, thrombocytopoaenia, fetal growth restriction and gestational age at onset of pre-eclampsia < 34 weeks. Patients meeting these crtieria are selected and their medical records are sampled from the first identification of their pregnancy and live birth. Patients with diabetes mellitus, chronic renal failure, hepatitis, HELLP syndrome, eclampsia, hematological co-morbidities, anticoagulant drug use, smoking, anemia and intrauterine fetal demise are excluded from the study. Control group is identified as healthy pregnant women in third trimester. Patients who delivered before 34 weeks of gestation and those who had blood tests in case of labor were not included in the control group.

Recruited patients were classified in five groups as $\mathrm{GH}$, mild-PE, severe$\mathrm{PE}$, cronic hypertension and control. Among these five groups, hematological parameters of the patients at the time of the diagnosis were compared. All of these parameters were sampled within the third trimester of the pregnancies. In all patients, a $2 \mathrm{ml}$ blood samples were taken into $2.0 \mathrm{mg} / \mathrm{ml}$ EDTA-2K containing pink sampling tubes by using 19-G needles. After ten minutes of centrifuging; hemoglobin $(\mathrm{Hb})$, platelet count $(\mathrm{PC})$, lymphocytes, neutrophils, Mean Platelet Volume (MPV), RDW, platelet distribution width (PDW), Plateletcrit (PCT) values were studied by using Cell Dyn 3700 (Abbott, IL, USA) blood count analyzer. Neutrophile Lymphocyte Ratio (NLR) was calculated by division of neutrophils to lymphocytes and Platelet Lymphocyte Ratio (PLR) was calculated by division of platelet count to lymphocytes.

\section{Asessment of data and statistical analysis \\ SPSS (Statistical Package for} Social Sciences) version 23.0 (SPSS Inc. USA) was used for statistical analysis. Kolmogorov-Smirnov test was performed for whole data for distribution of compliance before the assesment. When compairing the groups, in normaly distributed data, ANOVA (Analysis of Variance) test was used and for the remaining, Kruskal-Wallis test was chosen. For the interpretation of the data, 
Mann Whitney $U$ test was used to compare between two groups. Kruskal Wallis test was used to compare among more than two groups. Test results were assesed within $95 \%$ confidence interval and statistical significance was considered if $p<0.05$.

\section{Results}

Demographical and clinical parameters were shown in table 1 . There were no significant differences at mean age and number of pregnancies among five groups (respectively $p=0.51, p=0.52$ ). Weeks of delivery was significanty lower in the severe-PE group (32.6 \pm 2.5 week, $p<0.001)$ than other groups and indifferent among $\mathrm{GH}$, mild-PE, chronic hypertension and control groups $(p=0.650)$. Diastolic blood pressure was significantly higher in severe-PE group than other groups (mean $112.8 \pm 4.9$ mmhg, $p<0.001$ ), significantly lower in control group than other groups (mean 74 $\pm 5.8 \mathrm{mmhg}, \mathrm{p}<0.001$ ) and indifferent among $\mathrm{GH}$, mild-PE and chronic hypertension groups $(p=0.720)$. Systolic blood pressure was significantly higher in severe-PE group than other groups (mean $164.7 \pm 8.1 \mathrm{mmhg}, \mathrm{p}<0.001$ ), significantly lower in control group than other groups (mean $74 \pm 5.8 \mathrm{mmhg}$, $\mathrm{p}<0.001$ ) and indifferent among $\mathrm{GH}$, mild$P E$ and chronic hypertension groups $(p=$ 0.510). 24-hour urinary proteinuria was significantly higher in severe-PE group than other groups $(4.8 \pm 1.8$ gram, $\mathrm{p}<0.001$ ) and indifferent amoung $\mathrm{GH}$, chronic hypertension and control groups.

Table 1: Maternal demographical and clinical features of the patients among the groups.

\begin{tabular}{lcccccc}
\hline & $\begin{array}{c}\text { GH } \\
(\mathbf{n = 7 3})\end{array}$ & $\begin{array}{c}\text { Mild-PE } \\
(\mathbf{n = 1 7 5 )}\end{array}$ & $\begin{array}{c}\text { Severe-PE } \\
(\mathbf{n = 1 2 3})\end{array}$ & $\begin{array}{c}\mathbf{C H} \\
(\mathbf{n = 4 1 )}\end{array}$ & $\begin{array}{c}\text { Control } \\
(\mathbf{n = 1 7 1})\end{array}$ & $\mathbf{p}^{\mathbf{a}}$ \\
\hline Age (years) & $29.8 \pm 5.5$ & $29.0 \pm 5.9$ & $29.9 \pm 6.0$ & $30.2 \pm 5.1$ & $29.2 \pm 6.3$ & 0.510 \\
\hline Weeks of delivery & $37.6 \pm 1.5$ & $37.4 \pm 1.3$ & $32.6 \pm 2.5$ & $37.8 \pm 1.1$ & $36.0 \pm 2.8$ & $<\mathbf{0 . 0 0 1}$ \\
\hline No. of pregnancies $(\mathbf{n})$ & $1.8 \pm 0.8$ & $1.8 \pm 0.8$ & $1.7 \pm 0.7$ & $2.5 \pm 0.9$ & $2.5 \pm 1.3$ & 0.520 \\
\hline Systolic BP $(\mathbf{m m H g})$ & $145.8 \pm 8.7$ & $163.8 \pm 13.7$ & $164.7 \pm 8.1$ & $146.4 \pm 8.2$ & $112 \pm 11.4$ & $<\mathbf{0 . 0 0 1}$ \\
\hline Diastolic BP $(\mathbf{m m H g})$ & $91 \pm 3.8$ & $93 \pm 4.7$ & $112.8 \pm 4.9$ & $91 \pm 1.9$ & $74 \pm 5.8$ & $<\mathbf{0 . 0 0 1}$ \\
\hline $\begin{array}{l}\text { Urinary protein (gram/ } \\
\text { 24 hours) }\end{array}$ & $0.1 \pm 0.05$ & $1.0 \pm 0.6$ & $4.8 \pm 1.8$ & $0.2 \pm 0.12$ & $0.1 \pm 0.06$ & $<\mathbf{0 . 0 0 1}$
\end{tabular}

Data are given as mean \pm standard deviation. $p<0.05$ was considered significant. BP blood pressure GH-gestational hypertension, mild-PE mild preeclampsia, severe-PE severe preeclampsia, $\mathrm{CH}$ cronik hypertension. ${ }^{a}$ Kruskal Wallis test.

Comparison of the hematological parameters among all groups was shown in table 2. MPV was found significantly higher in severe-PE group than other groups $(<0.001)$ and indifferent among mild-PE, GH, chronic hypertension and control groups $(p=0.116)$. NLR, Hb, PCT and PLR were found unchanged among the groups (respectively $p=0.102$, $p=0.571, p=0.571, p=0.102)$. $P C$ was found significantly lower in severe-PE group than other groups $(p=0.01)$ and found indifferent among mild-PE, GH, chronic hypertension and control groups $(p=0.110)$. RDW was found significantly higher in severe-PE group than other groups $(p=0.01)$. PDW was found significantly lower in control group than other groups $(p<0.001)$. 
Table 2: Comparison of hematological parameters among all groups.

\begin{tabular}{lcccccc}
\hline $\begin{array}{l}\text { Hematologic } \\
\text { parameters }\end{array}$ & $\begin{array}{c}\text { Severe-PE } \\
(\mathbf{n}=\mathbf{1 2 3})\end{array}$ & $\begin{array}{c}\text { Mild-PE } \\
(\mathbf{n}=\mathbf{1 7 5})\end{array}$ & $\begin{array}{c}\mathbf{G H} \\
(\mathbf{n}=\mathbf{7 3})\end{array}$ & $\begin{array}{c}\mathbf{C H} \\
(\mathbf{n = 4 1 )}\end{array}$ & $\begin{array}{c}\text { Control } \\
(\mathbf{n = 1 7 1})\end{array}$ & $\mathbf{p}^{\mathbf{a}}$ \\
\hline MPV & $9,42 \pm 1,57$ & $8,91 \pm 1,51$ & $8,67 \pm 1,23$ & $8,55 \pm 0,21$ & $8.44 \pm 1.23$ & $<\mathbf{0 . 0 0 1}$ \\
\hline $\mathbf{R D W}$ & $16.63 \pm 1.81$ & $16.19 \pm 1.99$ & $16.13 \pm 1.69$ & $16.12 \pm 0.43$ & $16.10 \pm 0.47$ & $\mathbf{0 . 0 1}$ \\
\hline $\mathbf{P D W}$ & $17.76 \pm 2.15$ & $17.72 \pm 1.91$ & $17.70 \pm 1,56$ & $17.42 \pm 0.9$ & $16.88 \pm 0.5$ & $<\mathbf{0 . 0 0 1}$ \\
\hline $\mathbf{P C T}$ & $0.203 \pm 0.10$ & $0.202 \pm 0.06$ & $0.204 \pm 0.11$ & $0.203 \pm 0.12$ & $0.203 \pm 0.02$ & 0.571 \\
\hline $\mathbf{N L R}$ & $8.19 \pm 12.04$ & $5.55 \pm 7.03$ & $5.38 \pm 3.24$ & $4.95 \pm 3.36$ & $5.02 \pm 3.36$ & 0.102 \\
\hline Hb & $12.16 \pm 1.6$ & $12,10 \pm 1.4$ & $12,18 \pm 1.4$ & $12,2 \pm 0.8$ & $11.9 \pm 1.3$ & 0.571 \\
\hline PC & $216.9 \pm 88.5$ & $230.9 \pm 70.9$ & $239.6 \pm 55.5$ & $231.9 \pm 40.8$ & $229.72 \pm 72.6$ & $\mathbf{0 . 0 1}$ \\
\hline PLR & $129.45 \pm 75.3$ & $145.19 \pm 162.6$ & $152.9 \pm 133.8$ & $153.82 \pm 97.5$ & $155.9 \pm 113.8$ & 0.102 \\
\hline
\end{tabular}

Data are given as mean \pm standard deviation. $p<0.05$ was considered significant. GH- gestational hypertension, mild-PE mild preeclampsia, severe-PE severe preeclampsia, $\mathrm{CH}$ cronik hypertension. MPV mean platelet volume, RDW red cell distribution width, PDW platelet distribution widht, PCT plateletcrit, NLR neutrophile lymphocites ratio, Hb hemoglobin, PC platelet count, PLR platelet lymphocites ratio. ${ }^{a}$ Kruskal Wallis test

Comparison of the hematological parameters among mild-PE, $\mathrm{GH}$, chronic hypertension and control groups was shown in table 3. MPV was found indifferent among mild-PE, $\mathrm{GH}$, chronic hypertension and control groups $(p=0.116)$. RDW was found significantly higher in mild-PE group than $\mathrm{GH}$, chronic hypertension and control groups $(p=0.01)$. PDW was found significantly lower in control group than $\mathrm{GH}$, chronic hypertension and mild-PE groups $(p<0.001, p<0.001$, respectively $)$. NLR, $\mathrm{Hb}, \mathrm{PC}, \mathrm{PCT}$ and PLR were insignificantly different among mild-PE, $\mathrm{GH}$, chronic hypertension and control groups $(p=0.700, p=0.655, p=0.110$, $p=0.570, p=0.320$, respectively).

Table 3: Comparison of the hematological parameters among mild-PE, GH, chronic hypertension and control groups.

\begin{tabular}{lcc|ccc}
\hline $\begin{array}{l}\text { Hematologic } \\
\text { parameters }\end{array}$ & $\begin{array}{c}\text { Control } \\
(\mathbf{n}=\mathbf{1 7 1})\end{array}$ & $\begin{array}{c}\text { Mild-PE } \\
(\mathbf{n}=\mathbf{1 7 5})\end{array}$ & $\begin{array}{c}\mathbf{G H} \\
(\mathbf{n}=\mathbf{7 3})\end{array}$ & $\begin{array}{c}\mathbf{C H} \\
(\mathbf{n}=\mathbf{4 1})\end{array}$ & $\mathbf{p}^{\mathbf{a}}$ \\
\hline MPV & $8.44 \pm 1.23$ & $8,91 \pm 1,51$ & $8,67 \pm 1,23$ & $8,55 \pm 0,21$ & 0.116 \\
\hline RDW & $16.10 \pm 0.47$ & $16.19 \pm 1.99$ & $16.13 \pm 1.69$ & $16.12 \pm 0.43$ & $\mathbf{0 . 0 1 0}$ \\
\hline PDW & $16.88 \pm 0.5$ & $17.72 \pm 1.91$ & $17.70 \pm 1,56$ & $17.42 \pm 0.9$ & $<\mathbf{0 . 0 0 1}$ \\
\hline PCT & $0.203 \pm 0.02$ & $0.202 \pm 0.058$ & $0.204 \pm 0.11$ & $0.203 \pm 0.12$ & 0.570 \\
\hline NLR & $5.02 \pm 3.36$ & $5.55 \pm 7.03$ & $5.38 \pm 3.24$ & $4.95 \pm 3.36$ & 0.700 \\
\hline Hb & $11.9 \pm 1.3$ & $12,1 \pm 1.4$ & $12,2 \pm 1.4$ & $12,2 \pm 0.8$ & 0.655 \\
\hline PC & $229.7 \pm 72.6$ & $230.9 \pm 70.9$ & $239.6 \pm 55.5$ & $231.9 \pm 40.8$ & 0.110 \\
\hline PLR & $155.9 \pm 113.8$ & $145.2 \pm 162.3$ & $152.9 \pm 133.8$ & $153.8 \pm 97.5$ & 0.320 \\
\hline
\end{tabular}

Data are given as mean \pm standard deviation. $p<0.05$ was considered significant.GH- gestational hypertension, mild-PE mild preeclampsia, $\mathrm{CH}$ cronik hypertension. MPV mean platelet volume, RDW red cell distribution width, PDW platelet distribution widht, PCT plateletcrit, NLR neutrophile lymphocites ratio, Hb hemoglobin, $P C$ platelet count, PLR platelet lymphocites ratio. ${ }^{a}$ Kruskal Wallis test

Comparison of the hematological parameters among $\mathrm{GH}$, chronic hypertension and control groups was shown in table 4. PDW was found significantly lower in control group than chronic hypertension and $\mathrm{GH}$ groups $(p<0.001)$. MPV, RDW, NLR, Hb, PC,
PCT and PLR were insignificantly different among $\mathrm{GH}$, chronic hypertension and control groups $(p=0.369, p=0.501, p=0.505, p=0.513$, $p=0.110, \quad p=0.571, \quad p=0.120$, respectively). 
Table 4: Comparison of the hematological parameters among $\mathrm{GH}$, chronic hypertension and control groups.

\begin{tabular}{lcccl}
\hline $\begin{array}{l}\text { Hematologic } \\
\text { parameters }\end{array}$ & $\begin{array}{c}\text { Control } \\
(\mathbf{n}=\mathbf{1 7 1})\end{array}$ & $\begin{array}{c}\text { GH } \\
(\mathbf{n}=\mathbf{7 3})\end{array}$ & $\begin{array}{c}\mathbf{C H} \\
(\mathbf{n}=\mathbf{4 1})\end{array}$ & $\mathbf{p}^{\mathbf{a}}$ \\
\hline MPV & $8.44 \pm 1.23$ & $8,67 \pm 1,23$ & $8,55 \pm 0,21$ & 0.369 \\
\hline RDW & $16.10 \pm 0.47$ & $16.13 \pm 1.69$ & $16.12 \pm 0.43$ & 0.501 \\
\hline PDW & $16.88 \pm 0.5$ & $17.70 \pm 1,56$ & $17.42 \pm 0.9$ & $<0.001$ \\
\hline PCT & $0.203 \pm 0.02$ & $0.204 \pm 0.11$ & $0.203 \pm 0.12$ & 0.571 \\
\hline NLR & $5.02 \pm 3.36$ & $5.38 \pm 3.24$ & $4.95 \pm 3.36$ & 0.505 \\
\hline Hb & $11.9 \pm 1.3$ & $12,18 \pm 1.4$ & $12,19 \pm 0.8$ & 0.513 \\
\hline PC & $229.7 \pm 72.6$ & $239.6 \pm 55.5$ & $231.9 \pm 40.8$ & 0.110 \\
\hline PLR & $155.9 \pm 113.78$ & $152.9 \pm 133.78$ & $153.8 \pm 97.45$ & 0.120 \\
\hline
\end{tabular}

Data are given as mean \pm standard deviation. $p<0.05$ was considered significant.GH-gestational hypertension, $\mathrm{CH}$ cronik hypertension. MPV mean platelet volume, RDW red cell distribution width, PDW platelet distribution widht, PCT plateletcrit, NLR neutrophile lymphocites ratio, $\mathrm{Hb}$ hemoglobin,PC platelet count, PLR platelet lymphocites ratio. ${ }^{a}$ Kruskal Wallis test.

Comparison of the hematological parameters between $\mathrm{GH}$ and chronic hypertension groups was shown in table 5. MPV, RDW, PDW, NLR, Hb, PC, PCT and PLR were insignificantly different among $\mathrm{GH}$ and chronic hypertension groups $(p=0.621, p=0.752, p=0.102$, $p=0.232, \quad p=0.812, p=0.110, p=0.120$, $p=0.371$, respectively).

Table 5: Comparison of the hematological parameters between $\mathrm{GH}$ and chronic hypertension groups.

\begin{tabular}{lccc}
\hline $\begin{array}{l}\text { Hematologic } \\
\text { parameters }\end{array}$ & GH $(\mathbf{n}=\mathbf{7 3})$ & $\mathbf{C H}(\mathbf{n = 4 1 )}$ & $\mathbf{p}^{\mathbf{a}}$ \\
\hline MPV & $8,67 \pm 1,23$ & $8,55 \pm 0,21$ & 0.621 \\
\hline RDW & $16.13 \pm 1.69$ & $16.12 \pm 0.43$ & 0.752 \\
\hline PDW & $17.70 \pm 1,56$ & $17.42 \pm 0.9$ & 0.102 \\
\hline PCT & $0.204 \pm 0.11$ & $0.203 \pm 0.12$ & 0.371 \\
\hline $\mathbf{N L R}$ & $5.38 \pm 3.24$ & $4.95 \pm 3.36$ & 0.232 \\
\hline Hb & $12,3 \pm 1.42$ & $12,2 \pm 0.8$ & 0.812 \\
\hline PC & $239.6 \pm 55.5$ & $231.9 \pm 40.8$ & 0.110 \\
\hline PLR & $152.9 \pm 133.9$ & $153.8 \pm 97.5$ & 0.120 \\
\hline
\end{tabular}

Data are given as mean \pm standard deviation. $p<0.05$ was considered significant.GH- gestational hypertension, $\mathrm{CH}$ cronik hypertension. MPV mean platelet volume, RDW red cell distribution width, PDW platelet distribution widht, PCT plateletcrit, NLR neutrophile lymphocites ratio, Hb hemoglobin, PC platelet count, PLR platelet lymphocites ratio. ${ }^{a}$ Mann-Whitney $U$ test.

Comparison of the hematological parameters between $\mathrm{GH}$ and control groups was shown in table 6. PDW was significantly lower in control group than GH group $(p<0.001)$. MPV, RDW, NLR,
$\mathrm{Hb}, \mathrm{PC}$, PCT and PLR were insignificantly different among $\mathrm{GH}$ and control groups $(p=0.385, \quad p=0.752$, $p=0.420, p=0.387, p=0.110, p=0.371$, $p=0.130$, respectively). 
Table 6: Comparison of the hematological parameters between $\mathrm{GH}$ and control groups.

\begin{tabular}{lccc}
\hline $\begin{array}{l}\text { Hematologic } \\
\text { parameters }\end{array}$ & GH $(\mathbf{n}=\mathbf{7 3})$ & Control $(\mathbf{n = 1 7 1 )}$ & $\mathbf{P}^{\mathbf{a}}$ \\
\hline MPV & $8,67 \pm 1,23$ & $8.44 \pm 1.23$ & 0.385 \\
\hline RDW & $16.13 \pm 1.69$ & $16.10 \pm 0.47$ & 0.752 \\
\hline PDW & $17.70 \pm 1,56$ & $16.88 \pm 0.5$ & $<0.001$ \\
\hline PCT & $0.204 \pm 0.11$ & $0.203 \pm 0.02$ & 0.371 \\
\hline NLR & $5.38 \pm 3.24$ & $5.02 \pm 3.36$ & 0.420 \\
\hline Hb & $12,2 \pm 1.4$ & $11.9 \pm 1.3$ & 0.387 \\
\hline PC & $239.6 \pm 55.52$ & $229.7 \pm 72.6$ & 0.110 \\
\hline PLR & $152.9 \pm 133.78$ & $155.9 \pm 113.78$ & 0.130 \\
\hline
\end{tabular}

Data are given as mean \pm standard deviation. $p<0.05$ was considered significant. GH-gestational hypertension. MPV mean platelet volume, RDW red cell distribution width, PDW platelet distribution widht, PCT plateletcrit, NLR neutrophile lymphocites ratio, Hb hemoglobin, PC platelet count, PLR platelet lymphocites ratio. ${ }^{a}$ Mann-Whitney U test.

\section{Discussion}

In this study, MPV was significantly higher in severe-PE group and indifferent among mild-PE, GH, chronic hypertension and control groups. PC was found significantly lower in severe-PE group and found indifferent among mild-PE, $\mathrm{GH}, \quad$ chronic hypertension and control groups. RDW was found significantly higher in severePE group than the other groups, significantly higher in mild-PE group than $\mathrm{GH}$, chronic hypertension and control groups and insignificantly different among $\mathrm{GH}$, chronic hypertension and control groups. PDW was found significantly lower in control group than other groups and found indifferent among mild-PE, GH, chronic hypertension and severe-PE groups. NLR, Hb, PCT and PLR were found unchanged among the groups. There were no significant differences in hematological parameters between chronic hypertension and $\mathrm{GH}$ groups. There were found significantly higher PDW levels in gestational hypertensive disorders than control group.

Surgit et al.(7) reported that, although larger platelet volumes have been found to be associated with severity of hypertension, it is not well - known what induces thrombocytes in preeclampsia. But larger platelet volume is not a good predictor for PE progression. Bellos et al.(8) examined the data of 50 studies in their meta-analysis and reported that, MPV levels were higher in preeclamptic women than healthy pregnant women. Monteith et al.( 9) reviewed 9000 deliveries retrospectively and reported that, at time of diagnosis and late in the third trimester MPV levels were significantly increased than normotensive pregnant women. In those studies; MPV, PCT and RDW levels were compared between nonhypertensive pregnant women and women with severe-PE. Therefore, these results seemed to have lacks concerning the correlation between severity and progression of the hypertensive disorder. Similarly, in our study, MPV levels were found to be higher in severe preeclampsia group than other groups. Han et al.(11) studied MPV levels in the first and the third trimester pregnancies and suggested that it could be predicted progression to severe-PE with the first trimester MPV values. Yucel et al.(12) sampled 219 patients with groups of nonhypertensive pregnants, mild-PE and severe-PE and reported that RDW and MPV levels were higher in severe-PE women than non-hypertensive pregnant women and higher MPV and lower PCT may be markers for progression to severe-PE. Kanat et al.(13) reviewed 200 healthy women with 11-14 week-old pregnancies prospectively and reported that MPV was significantly higher in preeclamptic pregnancies and higher MPV levels could be useful to predict 
preeclampsia in early trimestr. In these studies, hematological parameters in different trimesters were compared with each other. Since hematological parameters may differ according to trimesters, comparing different trimester results may lead to erroneous results. In our study, all patients were evaluated in the third trimester.

Karateke et al.(14) found lower PCT levels in severe-PE patients. In our study, PCT levels did not differ between the groups. Yang et al.(15) found higher PDW levels in severe-PE patients and that may be a marker at determining severity of PE. In our study, PDW was found significantly elevated in severe-PE group but it wasn't related to severity of preeclampsia. Doğan et al.(16) suggested that a decrease in PC levels, an increase of MPV values and especially a decrease in PC/MPV ratio may indicate an important role for predicting the risk of PE but they have no role for prediction of the severity of PE. AISheeha et al.(17) found a relation between $P E$ progression and lower PC and higher PC/MPV ratio]. Similarly, we found increased MPV levels and lower platelet count in severe-PE patients but it wasn't related to severity of preeclampsia.

In their study, Serin et al. (18) showed that a relation between elevated NLR and severity of the PE. Kirbas et al.(19) found NLR is predictive at PE progression and found a relation between first trimester parameters and severity of PE and PLR was found slightly lower but not significantly lower in mild-PE patients. In our study, NLR and PLR levels did not differ between the groups. Akil et al. (20) mentioned the severity of hypertension in preeclampsia is related with decreased platelet count and elevated MPV and NLR, thus, these may be independent indicators in establishing the severity of PE. In those studies, because of the comparison of the severe preeclampsia group and the healthy patient group, there are deficiencies in predicting preeclampsia and showing its relationship with the severity of preeclampsia. Gogoi et al. (21) reported that the inflammatory markers NLR, PLR, RDW, and MPV were higher in women with pre-eclampsia. In a meta-analysis study performed by Adam et al (22), a total of 951 women with preeclampsia and 2024 control patients were included in the study and the results showed a significant difference in the RDW levels between preeclamptic women and the control patients; and women with severe preeclampsia were found to have significantly higher RDW levels compared to women with mildpreclampsia. Similarly, in our study RDW levels were significantly higher in severe$P E$ group than other groups but not significantly different among mild-PE, GH and control groups.

The great number of patients, the accurate classification of pregnancy hypertension groups and healthy control group and definitive separation and comparision of groups are the advantages that make our study different from other studies. Being a retrospective study is the limitation of our study.

In summary, we detected that the increase in preeclampsia severity was accompanied by an increase in RDW levels in our study. Therefore, hypertensive pregnant women with increased RDW levels detected during their follow-up in primary health care facilities should be referred to 2 nd and 3rd health care facilities. Thus, delay in diagnosis and treatment of preeclampsia can be prevented. 


\section{Conclusion}

MPV and RDW were found higher, and PC was found lower in severe-PE. PDW was found higher in gestational hypertensive disorders than healthy pregnant women. RDW levels elevation was found higher in accordance with the severity of preeclampsia. However, no significant changes were observed according to the severity of gestational hypertensive disorders. Further studies are needed to confirm these results.

\section{References}

1. Report of the National High Blood Pressure Education Program Working Group on High Blood Pressure in Pregnancy. Am J Obstet Gynecol. 07;183(1):S1-S22

2. Mol BW, Roberts $C T$, Thangaratinam $S$, Magee LA, de Groot CJ, Hofmeyr GJ. Preeclampsia.

Lancet. 2016;387(10022):999-1011. doi: 10.1016/S0140-6736(15)00070-7.

3. Sibai BM. Diagnosis, controversies, and management of the syndrome of hemolysis, elevated liver enzymes, and low platelet count. Obstet Gynecol. 2004;103(5 pt 1):981-991

4. 4. Macey MG, Bevan $S$, Alam $S$, Verghese L, Agrawal S, Beski S, et al. Platelet activation and endogenous thrombin potential in pre-eclampsia. Thromb Res [Internet]. 2010;125(3):e7681.

5. 5. Jakobsen C, Larsen JB, Fuglsang J, Hvas $A$, Jakobsen $C$, Larsen JB, et al. Platelet function in preeclampsia - a systematic review and meta-analysis Platelet function in preeclampsia - a systematic review and meta-analysis. Platelets [Internet]. 2019;0(0):1-14.

6. 6. Güngör $Z B$, Ekmekçi $H$, Tüten $A$, Toprak $S$. Is there any relationship between adipocytokines and angiogenesis factors to address endothelial dysfunction and platelet aggregation in untreated patients with preeclampsia? Arch Gynecol Obstet (2017) 296: 495

7. Surgit O, Pusuroglu H, Erturk M, Akgul O, Buturak A, Akkaya E, et al. Assessment of mean platelet volume in patients with resistant hypertension, controlled hypertension and normotensives. The Eurasian journal of medicine. 2015;47:79.

8. Bellos I, Fitrou G, Pergialiotis V, Papantoniou N, Daskalakis G. Mean platelet volume values in preeclampsia: $A$ systematic review and meta-analysis. Pregnancy Hypertens. 2018 Jul;13:17480.

9. Monteith C, Egan K, O'Connor H, Maguire $P$, Kevane B, Szklanna $P B$, et al. Early onset preeclampsia is associated with an elevated mean platelet volume (MPV) and a greater rise in MPV from time of booking compared with pregnant controls: results of the CAPE study. J Perinat Med. 2018 Nov;46(9):1010-5.

10. Practice ACoO. Practice bulletin\# 33: diagnosis and management of preeclampsia and eclampsia. Obstetrics \& Gynecology. 2002;99:159-67.

11. Han L, Liu X, Li H, Zou J, Yang Z, Han J. Blood Coagulation Parameters and Platelet Indices: Changes in Normal and Preeclamptic Pregnancies and Predictive Values for Preeclampsia. 2014;(Dd):1-14.

12. Yucel B, Ustun B. Neutrophil to lymphocyte ratio, platelet to lymphocyte ratio, mean platelet volume, red cell distribution width and plateletcrit in preeclampsia. Pregnancy Hypertens. 2017 Jan;7:29-32.

13. Kanat-pektas $M$, Yesildager $U$, Tuncer $N$, Arioz DT. Could mean platelet volume in late first trimester of pregnancy predict intrauterine growth restriction and preeclampsia? 2014;40(7):1840-5.

14. Karateke A, Kurt RK, Baloglu A. Relation of platelet distribution width (PDW) and platelet crit (PCT) to preeclampsia. Ginekol Pol. 2015 May;86(5):372-5.

15. Yang SW, Cho SH, Kwon HS, Sohn IS, Hwang HS. Significance of the platelet distribution width as a severity marker for the development of preeclampsia. European Journal of Obstetrics \& Gynecology and Reproductive Biology. 2014;175:107-11. 
16. Doğan K, Guraslan H, Senturk MB, Helvacioglu C, Idil S, Ekin M. Can Platelet Count and Platelet Indices Predict the Risk and the Prognosis of Preeclampsia? Hypertens Pregnancy [Internet]. 2015 Oct 2;34(4):434-42.

17. AlSheeha MA, Alaboudi RS, Alghasham MA, Iqbal J, Adam I. Platelet count and platelet indices in women with preeclampsia. Vascular health and risk management. 2016;12:477.

18. Serin S, Avci F, Ercan O, Kostu B, Bakacak M, Kiran $H$. Is neutrophil/lymphocyte ratio a useful marker to predict the severity of preeclampsia? Pregnancy Hypertens. 2016 Jan;6(1):22-5.

19. Kirbas A, Ersoy AO, Daglar K, Dikici $T$, Biberoglu EH, Kirbas O, et al. Prediction of preeclampsia by first trimester combined test and simple complete blood count parameters. Journal of clinical and diagnostic research: JCDR. 2015;9:QC20.

20. Akıl MA, Bilik MZ, Acet $H$, Tunç SY, Ertaş $F$, Aydın M, et al. Mean platelet volume and neutrophil lymphocyte ratio as new markers of preeclampsia severity. Age (years). Koşuyolu Hearth Journal 2015;18(2):84-8

21. Gogoi P1, Sinha P1, Gupta B2, Firmal P2, Rajaram S2 . Neutrophil-to-lymphocyte ratio and platelet indices in pre-eclampsia. Int J Gynaecol Obstet. 2019 Jan;144(1):16-20.

22. Adam I, Mutabingwa TK, Malik EM. Red cell distribution width and preeclampsia: a systematic review and meta-analysis. Clin Hypertens. 2019 Jul 15;25:15. 